Primljen / Received: 2.5.2012.

Ispravljen / Corrected: 6.9.2012.

Prihvaćen / Accepted: 18.9.2012.

Dostupno online / Available online: 15.10.2012.

\title{
Visual inspection in evaluation of bridge condition
}

Authors:

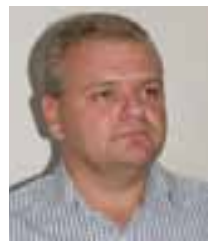

Danijel Tenžera, B.Sc. CE

Croatian roads, Zagreb

danijel.tenzera@hrvatske-ceste.hr

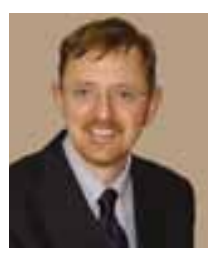

Asst.Prof. Goran Puž, Ph.D. CE

Institut IGH d.d., Zagreb

goran.puz@igh.hr

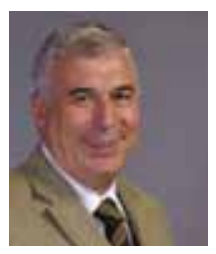

Prof. Jure Radić, Ph.D. CE

University of Zagreb

Faculty of Civil Engineering

jradic@grad.hr

\section{Danijel Tenžera, Goran Puž, Jure Radić}

\section{Visual inspection in evaluation of bridge condition}

Given that visual inspection is vital when evaluating the condition of bridges, it plays a crucial role in planning the special maintenance works. At the beginning of 2012, a research was conducted in HAC (Croatian Highways) aiming to standardize evaluation of bridges. The bridge engineers had assessed a certain group of buildings, and their results were afterwards analysed using the mathematical statistics methods. The obtained results showed weaknesses in the existing evaluation system, and the conducted research created a base for improving aides for management, handbooks and procedures for bridge inspection.

Key words:

bridges, visual inspection, state evaluation, periodic maintenance

Prethodno priopćenje

\section{Danijel Tenžera, Goran Puž, Jure Radić}

\section{Vizualni pregled kao pomagalo za ocjenu stanja mostova}

Vizualni pregled je glavno pomagalo za ocjenjivanje stanja mostova, stoga ima presudan utjecaj na planiranje radova izvanrednog održavanja. U Hrvatskim cestama je početkom 2012. godine provedeno istraživanje s ciljem postizanja ujednačenosti pri ocjenjivanju mostova. Inženjeri za mostove ocijenili su određeni skup građevina, a potom su rezultati analizirani metodama matematičke statistike. Dobiveni rezultati upućuju na slabosti postojećeg sustava ocjenjivanja, a s provedenim istraživanjem stvorena je podloga za unaprjeđenje pomagala za gospodarenje, priručnika i postupaka za preglede mostova.

Ključne riječi:

mostovi, vizualni pregledi, ocjena stanja, izvanredno održavanje

Vorherige Mitteilung

Danijel Tenžera, Goran Puž, Jure Radić

\section{Sichtkontrolle als Stütze zur Bewertung des Brückenzustands}

Die Sichtkontrolle ist ein Haupthilfsmittel zur Bewertung des Zustands von Brücken und haben deshalb einen bedeutenden Einfluss auf die Planung von außerordentlichen Wartungsarbeiten. In der öffentlichen Einrichtung "Hrvatske ceste", die für den Bereich Straßenbau- und verwaltung zuständig ist, wurde eine Forschung mit dem Ziel durchgeführt, eine Standardisierung bei der Brückenbewertung zu erreichen. Brückeningenieure haben eine bestimmte Gruppe von Bauten bewertet und danach die Resultate mit Hilfe mathematischer statistischer Methoden analysiert. Die erhaltenen Resultate weisen auf eine Schwäche des bestehenden Bewertungssystems hin. Aufgrund der durchgeführten Forschung wurde eine Basis für eine Modernisierung des Brückenkontrollverfahrens sowie Verbesserung der Handbücher für die Brückenkontrolle geschaffen. 


\section{Introduction}

Various defects occur during the life span of all structures, and so they have to be remedied and kept in good state of repair. Structure management systems are developed so as to plan maintenance activities in such a way that they generate the lowest possible costs for users and operators alike. The condition of the structure, i.e. the level of its damage, must be determined, and then its further life is anticipated and maintenance activities are proposed. Most decisions relating to bridge maintenance are founded on assessments that are based on visual inspections conducted by specially trained engineers, using procedures and aids defined in the management system. To ensure uniformity and objectivity, the inspections are conducted using a standardized procedure which has been developing in Hrvatske ceste since 1995 under the name of HRMOS, and is based on the system used by the Danish Road Directorate [1, 2].

Processes causing deterioration of bridges mostly start without visible signs and are manifested only at a later phases through occurrences visible on the surface of the structure. During inspections, engineers have to observe, register and recognize those occurrences that are significant for assessing condition of the bridge and its equipment, i.e. the indications or manifestations of processes leading to damage. Bridge condition is rated through interpretation of occurrences that have been identified and registered, and then these ratings are combined into a single rating valid for the entire structure. Bridge maintenance activities and costs are planned by setting priorities and anticipating the future life of the structure (Figure 1).

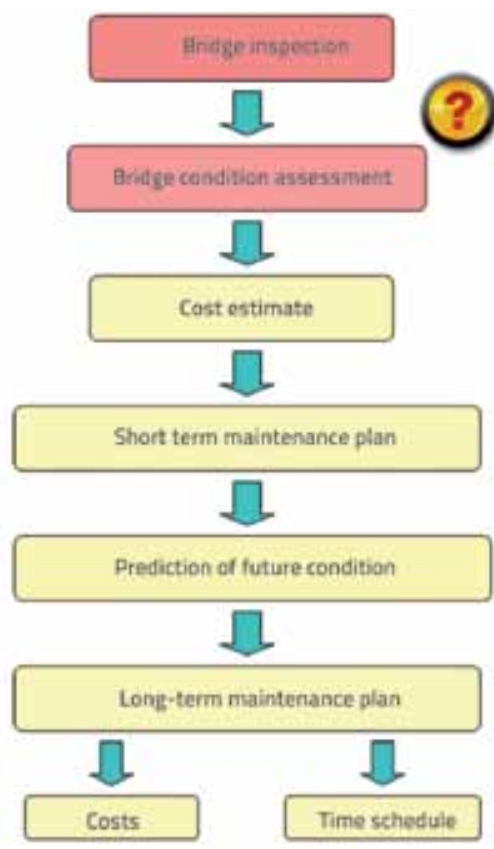

Figure 1. Simplified scheme of the process used for planning periodic maintenance of bridges
Regardless of the fact that many structure testing methods have so far been developed, visual inspection is likely to remain the most significant aid for bridge condition assessment, especially for smaller typical structures. The quality and uniformity of visual inspection results greatly depend on the motivation, qualification and equipment of persons conducting these inspections, and the efficiency of management system in the sphere of maintenance planning significantly depends on the uniformity of results obtained by visual inspection, i.e. on the assessment of category of damage, which is directly related to the scope and type of subsequent repairs [3].

Past experience and some research results show that assessing condition of a bridge or a part of bridge by visual inspection is unreliable, as it often does not reveal real bridge condition, nor does it point to correct priorities when decisions about repair works are made. At the scientific level, this problem is treated in psychology, i.e. it is covered in the field of psychology focusing on sensations and perceptions. The sensation is a process activated by the excitation energy detection and coding in the sensory system, while perception is an active process of organizing, integrating and interpreting sensory information. In fact, different people respond differently to the same external excitation and sensation. Perception is an individual and situation-related category, and is hence not an objective photographic copy of reality but rather the subjective experience and interpretation of the observer. More specifically, perception is dependent on a number of psychological factors, such as expectations, attitude, type of information (e.g. different instructions), quantity of information, insight into the formation process, motivation, sociocultural influences, etc. $[4,5]$. This means that findings made by different bridge inspectors can not be identical. Nevertheless, these differences can be reduced, i.e. a greater objectivity of these inspections can be achieved.

The purpose of this study is to evaluate the level of uniformity/similarity in assessments made by engineers in charge of bridge inspections, as these assessments are the basis for planning periodic maintenance activities. Periodic maintenance activities for roads and road structures are occasional or periodic works for which technical documentation is required. They are conducted to locally repair road elements, to improve safety, stability and durability of roads and road structures, and to increase the level of traffic safety. Periodic maintenance implies a number of significant activities that are conducted to establish a sustainable situation, i.e. to restore initial properties of the structure (mechanical resistance and stability, safety, etc.). From the construction standpoint, these works are repairs, alterations, and rehabilitations that are made to ensure safety or usability of bridges, and remedial actions on dilapidated, deteriorated or heavily damaged parts of structures, as well as other similar activities.

This study consists in assessment of bridge damage by visual inspection in concrete situations, using the road network management methodology applicable in the Republic of 
Croatia. The results of the study are conclusions pointing to the direction for further development in this field. The group of fifteen persons that took part in the study is formed of Hrvatske ceste employees, all engineers with considerable experience in the conduct of general and specific visual inspections of bridges situated within the Croatian road network.

\section{Regulatory framework}

The legislator has recognized great significance of structure maintenance activities and has started to regulate this field by prescribing requirements for the conduct of regular inspections of structures. It may reasonably be expected that, in the future, the responsibility for inspection and assessment of condition of structures will be made equal to the responsibility for construction work.

The fundamental document regulating the use and maintenance of structures is the Law on Physical Planning and Construction, in which the section entitled Use and Maintenance of Structures, i.e. its Articles 269 to 272, are directly relevant for management activity. A concrete framework for establishment of management system is set in Article 271 where it is stipulated that activities relating to structure condition monitoring, structure inspection, and determination of the need to make repairs, must be entrusted by the owner or operator of the structure/facility to persons meeting legal requirements for the conduct of these activities.

The mentioned law and the related ministerial-level byelaw, in which maintenance requirements will be specified, have not as yet been passed, although there is a real need for such documents. Activities relating to the testing and study of structures are also considered in Article 20 of the above mentioned Law. It is specified in this article that maintenance-related inspections should be conducted by competent persons, and that authorizations for the conduct of such inspections are given by the minister. According to the Law on Public Roads, the company Hrvatske ceste d.o.o. is responsible for management of a uniform road data base, and for ensuring in this way the technical and technological unity of the public road network. These data also include the data about bridges.

Inspections of road structures are conducted in accordance with the Byelaw on the Maintenance and Protection of Public Roads. Annual inspections of structures are conducted at least once in every two years, while main inspections are conducted at least once in every six years. Main inspections are made by competent persons from relevant road administration units, and by experts employed in specialized organizations or institutions.

\section{Conduct of inspections and assessment procedures}

\subsection{General}

Several assessment procedures have so far been developed in various parts of the world. They differ from one another by approach and by complexity of procedure [6]. Basic characteristics of Croatian system, which is the basic system in this study, is described in this section. A brief overview is also given of the system that has been developed in the USA [7], as it is there that the most comprehensive studies of the efficiency of visual inspections have been made [8].

In an attempt to objectively quantify bridge damage and defects, many countries have developed special aids related to bridge inspections, such as manuals, guidelines and calculation procedures. In many developed countries, this activity is conducted by specialists. This special approach is due to specific position of bridges when compared to other structures:

1. Bridges are made of parts that often differ from one another by material used, quality, exposure to various influences, and manufacturing procedure, which is why they deteriorate at a different rate, and are governed by principles subjected to different mechanisms.

2. In the course of a relatively long life span, bridge parts pass through typical phases of deterioration which are recognizable in case of a dominant process.

3. The deterioration process does not advance uniformly across the surface of the element as most types of damage have their originating point at places of initial defects, i.e. at places that are mostly exposed to aggressive action.

Bridge condition assessment procedures are based on the classification of damage into several categories covering comparable occurrences, so that reports and subsequent analyses can be made uniform, and so that the situation can be reduced to a number of types to which cost estimate items relating to repair can be associated. Thus, the following requirements have to be met by individual damage categories: - each category has to be clearly recognisable according to physical properties of the deterioration process, and according to functional properties of the structural element under study, - each category has to be associated with one or more bridge maintenance or bridge repair procedures.

As in some cases there are no warning signs in early phases of deterioration, it is clear that visual inspections can in most cases be considered insufficient for proper evaluation. However, as relevant testing is complex and expensive, most bridges of smaller size and significance are still evaluated on the basis of visual inspections only. The correlation between such evaluations and the real condition is greatly dependent on the experience and engineering judgement of the person conducting the inspection work.

\subsection{Bridge condition assessment system used on national roads of the Republic of Croatia}

The company Hrvatske ceste d.o.o. operates the national road network $6585 \mathrm{~km}$ in length, along which 1538 bridges of more than $2 \mathrm{~m}$ in span are located. Only the bridges of more than 5 
metres in span were included in the initial bridge management system. However, after the HRMOS system was included in 2001 in a more comprehensive road structure management system called "Hrvatske ceste Road Database" (BCP), the road culverts from 2 to 5 meters in span were also included in the system.

Fourteen regional units supervising national roads in the entire territory of the Republic of Croatia were established within the Maintenance Sector of the company Hrvatske ceste d.o.o. Funds for bridge maintenance, including bridge inspections, are planned through four-year programmes. Bridges situated along the national road network are inspected by teams each consisting of two civil engineers - inspectors - educated for the conduct of such inspections (the field training of inspectors was organized before the annual bridge inspection in 2006). These inspectors also propose repair activities. The usual time needed for fourteen inspection teams to complete bridge inspections along the entire national road network is three months.

The 2008-2010 database for bridges of more than 5 metres in span contains information on the condition of bridges and bridge elements for 1160 structures. However the number of bridges operated by $\mathrm{HC}$ has changed: 823 bridges were registered in 2012 on the national road network (the difference is due to the new classification of roads). Out of 718 girder

Table 1. Bridge elements assessed in the scope of the national road management system operated by Hrvatske ceste, with average ratings, situation in $\mathbf{2 0 1 0}$

\begin{tabular}{|c|c|c|}
\hline Element groups & Bridge elements & $\begin{array}{l}\text { Average } \\
\text { grade }\end{array}$ \\
\hline A & $\begin{array}{c}\text { Approaches and embankment } \\
\text { cones }\end{array}$ & 1,8 \\
\hline \multirow{3}{*}{ B Substructure } & $\begin{array}{c}\text { B1 Foundations of abutments } \\
\text { and piers }\end{array}$ & 1,6 \\
\hline & B2 Abutments & 1,6 \\
\hline & B3 Piers & 1,4 \\
\hline \multirow{4}{*}{ C Superstructure } & C 11 Main girders & 1,6 \\
\hline & C 12 Span structure & 1,6 \\
\hline & C 2 Expansion joints & 2,2 \\
\hline & C 3 Bearings & 1,4 \\
\hline \multirow{4}{*}{ D Equipment } & D 1 Pavement + walkway & 1,9 \\
\hline & D 21 Traffic barrier & 2 \\
\hline & D 22 Railing & 2 \\
\hline & D 3 Other & 2 \\
\hline $\begin{array}{l}\text { Bridge, general } \\
\text { rating }\end{array}$ & & 1,8 \\
\hline
\end{tabular}

bridges registered, in 587 cases girders are made of reinforced concrete, in 113 cases main girders are formed of prestressed concrete, and in 18 cases main girders are made of an another material (steel in most cases). In addition, 74 arch bridge were registered (34 masonry bridges, 39 concrete and reinforced concrete bridges, and 1 steel bridge), while main girders of the remaining 31 bridges have other static systems (frame, bracing, etc.).

The bridge monitoring information, i.e. the information on regular routine assessment of bridges along the Croatian road network, is relatively scarce. The inspection of a big number of structures was made in the scope of bridge cadastre establishment in mid-1980s [9]. On that occasion, bridges were evaluated based on visual inspection, using the following quality scale: good - slightly damaged - considerably damaged - more detailed inspection needed - dilapidated.

A six-category scale is used in the current bridge assessment system: from category 0 (no damage to bridge or bridge element) to category 5 (extensive damage registered). Categories 1 and 2 are mostly used to depict constructionrelated defects. The category 3 is used for elements undergoing the deterioration process, while highly deteriorated elements are included in categories 4 and 5 .

During general inspection of bridges, thirteen standard bridge elements are assessed, and then the general bridge rating is given. However, only twelve elements are shown in Table 1 as two elements (pavement and walkway) have been reduced to one (D1 pavement + walkway). Bridge classification by general ratings, made in 2010, is shown in Figure 2.

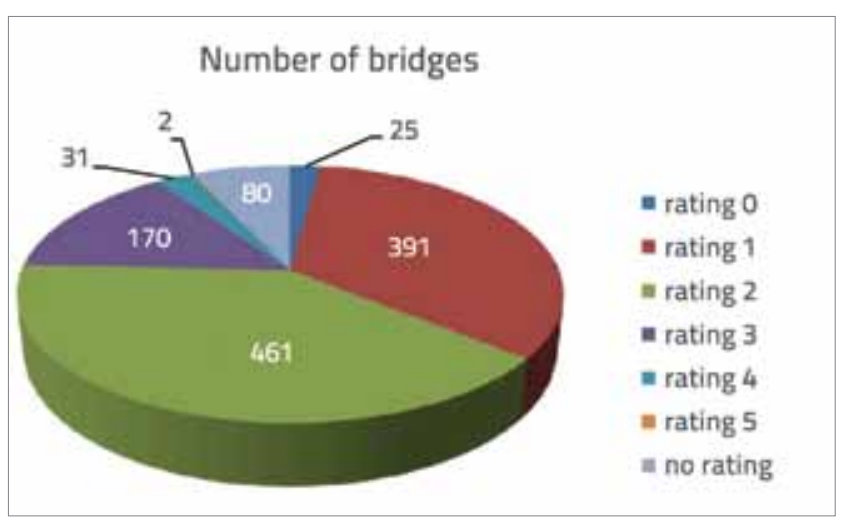

Figure 2. Condition of bridges on national roads of the Republic of Croatia - situation in 2010

The main objective of the system established in this way is to predict the bridge maintenance funding that will be needed over the next five years. In addition to the above presented system that is used on the national road network, the SGG system (structure management system) [10] has been introduced on the majority of the toll motorway network. The main difference between the two systems lies in the fact that HRMOS relies more on the quality of assessment made by the inspector who directly assesses individual bridge elements, 
while in case of SGG the procedure consists in inspection and registration of individual defects, and then this information is stored in computer memory and a special algorithm is used to calculate condition of each element.

\subsection{Grading system applied in the USA}

Since 1970, all federal states are required to organize bridge monitoring activity on all roads of national significance. National Bridge Inspection Standards - NBIS [11] were established for purposes of the Bridge Management System (BMS). According to these standards, bridges were divided into four main structural units that were separately assessed during inspection: superstructure, substructure, deck slab, and culverts.

The assessment procedure was conducted every two years. During such assessment, grades ranging from 1 to 9 were attributed to each of the four main parts of the bridge. The grades describe the level of deterioration, and so the grade " 9 " is given for a bridge without any damage and defects, while the grade " 0 " is given to the bridge that has deteriorated to such an extent that It can no longer be repaired.

However, after a long-term use, the following main deficiencies of the system were noticed:

- division of a bridge into parts is not sufficiently detailed for identification of appropriate maintenance strategies;

- grades used do not recognize the deterioration process nor the extent of damage to bridge parts;

- the grading system is highly subjective, as only a "general condition" of the bridge is evaluated.

The deficiencies of the early system have prompted development of new systems in 1990s. This development activity was supported by the American Association of State Highway and Transportation Officials (AASHTO), which is why the resulting system has gained a US wide significance. According to the new system, the bridge is divided into more elements and the condition of such elements is measured according to the scale reflecting a usual deterioration process and the effect of deterioration on the usability. Ratings depicting bridge condition are defined in such a way that they point to necessary maintenance activities, i.e. to the cost and duration of required works and, in principle, they are defined separately for each process leading to bridge deterioration. Two significant data are collected for each element and for each relevant deterioration process:

- condition: level of deterioration;

- extent: number of elements affected by the damage.

\section{US study of effectiveness of visual inspections}

The study of effectiveness of visual inspections was made in response to relative uncertainty of results on which the management system is based, i.e. after it was established that there is a great discrepancy of results in case the same structure is inspected by several inspectors. A comprehensive study on this issue was conducted by the Federal Highway Administration's Nondestructive Evaluation Validation Center (NDEVC) in 2001 [8]. Thestudy consisted of a preparatory part: prior experiencegathering and analysis of documents, and of a practical part: inspection by 49 state inspectors from all over the US who separately performed six regular inspections, two detailed inspections, and two additional inspections, based on standards used in federal states from which they originate. The basic conclusions of the study can be summarized as follows:

1. Most reviewers did not notice any occurrences that would greatly affect bearing capacity and usability of bridge elements: less than $10 \%$ of inspectors identified deformations or excessive deflection of the structure. Less than $50 \%$ of inspectors assessed condition of bearing elements as critical, when it was in fact critical.

2. Assessments of the same elements differed greatly: for each element that can be associated with one out of six possible ratings, inspectors gave as many as four to five different ratings. The statistical treatment revealed that $95 \%$ of bridge element assessments/ratings varied on an average by two ratings, while $68 \%$ of ratings differed by one rating.

3. Some inspectors performed their work with negligence:

- they took less photographs than required,

- field observation notes were not harmonized with regard to quality and quantity,

- inspection time varied greatly: the time for regular and detailed inspections ranged from several minutes to several hours.

4. When inspectors can not decide for either a lower or a higher ranking, they tend to group ratings toward the middle of the scale. For that reason, elements that are in better condition get lower ratings while those in poorer condition get better ranking.

5. Some significant factors that influence ratings are:

- uneasiness of inspectors because of traffic operated during their work,

- lack of specialized knowledge,

- level of lighting at the surface that is being inspected,

- lack of knowledge about bridge maintenance history, and

- influence of wind, rain and other weather related elements.

6. Some significant damage was not identified by detailed inspection. This especially concerns narrower cracks and occurrences that are difficult to identify. In addition, it was revealed that defects not identified during regular inspections are not likely to be identified even if frequency of detailed inspections is increased.

7. Inspectors can be classified into several groups according to their approach to work and inspection results: those inspectors who notice small negligible damage are oriented locally to bridge parts, while those who generally register greater damage take into account the entire structure of the bridge. Inspectors whose ratings are lower than average ratings on one bridge are likely to give similar ratings on other bridges. 
Table 2. Form used to estimate damage to bridges comprised by the survey

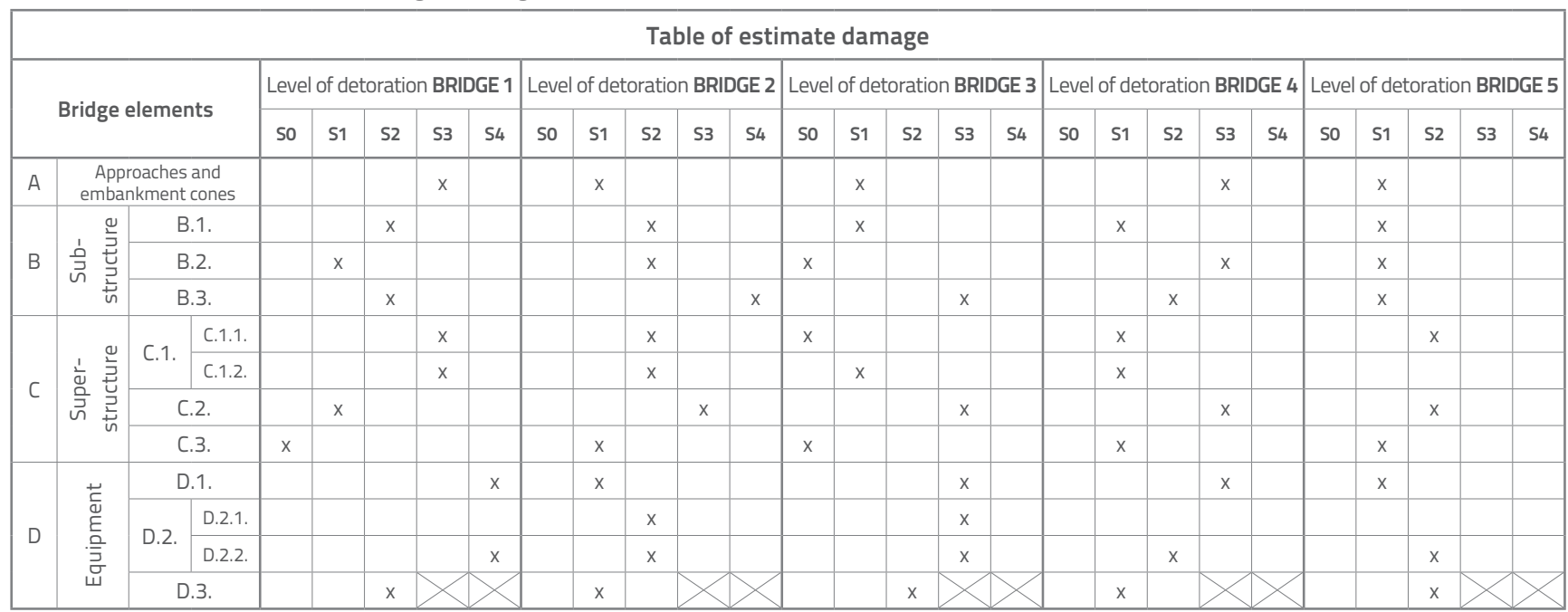

\section{Study conducted in Croatia in 2012}

\subsection{Methodology and initial assumptions}

Some inconsistencies were revealed following study of the database containing ratings made by bridge engineers in the scope of regular inspections. Concretely, most conclusions from the cited American study can also be applied to our circumstances. This is why a study was conducted to test the work of 15 inspectors, experienced engineers from various Hrvatske ceste units, who evaluated the level of damage on five different bridges. The catalogue of damage, and the grading system used in the study, were intentionally modified with respect to the system used in normal practice, so as to avoid routine ranking.

Older reinforced concrete and prestressed concrete bridges were used as the sample, and rankings ranged from SO (completely undamaged element) to $\mathbf{S} 4$ (unusable element). For each of 12 bridge elements, typical defects and ratings associated to them were described in the catalogue given to inspectors before inspection. Photographs of all bridge elements to be tested were also given to inspectors. The inspectors were asked to enter ratings in the form presented in Table 2. Ratings S3 and S4, for the element group D.3, were not in the rating system and were marked as such in the table (ratings entered are reference values, i.e. they represent the position taken be the survey leader). Concrete designations of marks assigned to individual elements are given in Table 1. According to rating instructions from 2006, the overall rating of the bridge is considered equal to the worst rating of the ratings for the following elements: span structure, pier with head beam, abutment, foundations (for piers and abutments), and riverbed.

\subsection{Test results}

Statistical indicators used in the analysis of bridge element results are an average numerical value of the level of damage, standard deviation, median, and mode of statistical redistribution in the group of values [12]. The reiteration frequency of the mode as a form of quantitative value occurring in the analysis of results is related to the frequency of reiteration of the most frequent damage rating within the group under study. If two modal values with equal frequencies occur in a group then the higher modal value with the corresponding frequency is presented in the table, as this value stands for a worse rating of damage. Test results are presented in Table 3.

Standard deviation results representing dispersion from an average numerical value of the level of damage within limits for one higher/lower rating $(\sigma<1.0)$ occur in $78.3 \%$ of bridge element rating results. Greater deviation, i.e. greater dispersion for an average numerical value of level of damage within limits for two or more than two higher/lower ratings ( $\sigma \geq 1.0$ ) occur in $16.7 \%$ of bridge element rating results. This interval comprises individual groups of damage to substructure and superstructure and to bridge equipment, with result dispersion of no more than 1.3.

An exceptional damage to abutment and pier foundations in case of bridge 1 shows the dispersion of results of 1.5 (Figure 3). This deviation is typical for the problem of perception: the elements under study (foundations) can not be inspected (Figure 4), but the condition of the entire structure points to the problem of scouring in the riverbed, i.e. to the mechanism that is not visible on the element itself (pier), but can be determined via deformation that can be seen by naked eye at the railing line (Figure 5).

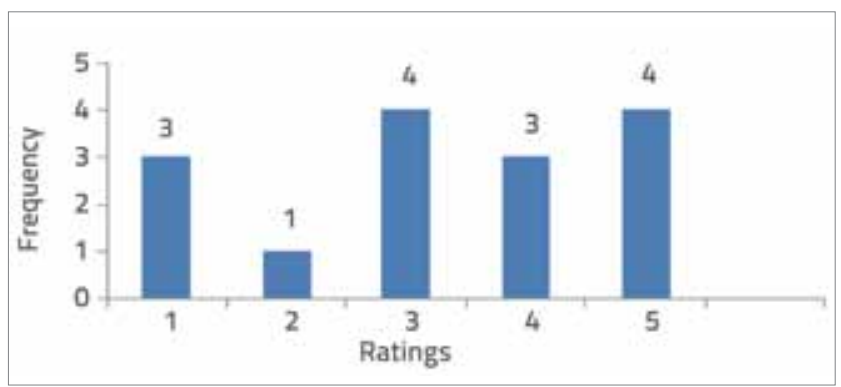

Figure 3. Distribution of ratings for abutment and pier foundations (Bridge 1) 
Table 3. Analysis of bridge inspection results

\begin{tabular}{|c|c|c|c|c|c|c|}
\hline Element & Statistical indicator & Bridge 1 & Bridge 2 & Bridge 3 & Bridge 4 & Bridge 5 \\
\hline \multirow{5}{*}{$\begin{array}{c}\text { A. } \\
\text { Approaches and } \\
\text { embankment } \\
\text { cones }\end{array}$} & Standard rating & 3,1 & 1,6 & 2,0 & 3,3 & 2,1 \\
\hline & Standard deviation & 0,9 & 0,6 & 0,4 & 0,7 & 0,3 \\
\hline & Median & 3 & 2 & 2 & 3 & 2 \\
\hline & Mode & 3 & 1 & 2 & 3 & 2 \\
\hline & Frequency & 6 & 7 & 13 & 9 & 14 \\
\hline \multirow{5}{*}{$\begin{array}{c}\text { B.1. } \\
\text { Foundations for } \\
\text { embankments } \\
\text { and piers }\end{array}$} & Standard rating & 3,3 & 2,7 & 2,3 & 3,1 & 2,1 \\
\hline & Standard deviation & 1,5 & 0,8 & 0,9 & 1,1 & 0,3 \\
\hline & Median & 3 & 3 & 2 & 3 & 2 \\
\hline & Mode & 5 & 2 & 2 & 4 & 2 \\
\hline & Frequency & 4 & 7 & 9 & 6 & 14 \\
\hline \multirow{5}{*}{$\begin{array}{c}\text { B.2. } \\
\text { Abutments }\end{array}$} & Standard rating & 2,3 & 2,5 & 2,5 & 3,2 & 2,5 \\
\hline & Standard deviation & 0,5 & 0,6 & 1,0 & 0,9 & 0,7 \\
\hline & Median & 2 & 2 & 2 & 3 & 2 \\
\hline & Mode & 2 & 2 & 2 & 3 & 2 \\
\hline & Frequency & 10 & 9 & 7 & 7 & 9 \\
\hline \multirow{5}{*}{$\begin{array}{l}\text { B.3. } \\
\text { Piers }\end{array}$} & Standard rating & 2,7 & 4,1 & 3,3 & 2,5 & 2,1 \\
\hline & Standard deviation & 1,0 & 0,5 & 0,9 & 0,5 & 0,4 \\
\hline & Median & 2 & 4 & 3 & 3 & 2 \\
\hline & Mode & 2 & 4 & 3 & 3 & 2 \\
\hline & Frequency & 9 & 11 & 6 & 8 & 13 \\
\hline \multirow{5}{*}{$\begin{array}{l}\text { C.1.1. } \\
\text { Main girder }\end{array}$} & Standard rating & 3,8 & 2,5 & 2,5 & 2,2 & 2,6 \\
\hline & Standard deviation & 0,4 & 0,7 & 0,7 & 0,7 & 0,5 \\
\hline & Median & 4 & 2 & 2 & 2 & 3 \\
\hline & Mode & 4 & 2 & 2 & 2 & 3 \\
\hline & Frequency & 12 & 9 & 10 & 11 & 9 \\
\hline \multirow{5}{*}{$\begin{array}{c}\text { C.1.2. } \\
\text { Span structure }\end{array}$} & Standard rating & 3,7 & 2,5 & 2,5 & 2,4 & 2,6 \\
\hline & Standard deviation & 0,7 & 0,7 & 0,7 & 0,9 & 0,5 \\
\hline & Median & 4 & 2 & 2 & 2 & 3 \\
\hline & Mode & 4 & 2 & 2 & 2 & 3 \\
\hline & Frequency & 10 & 7 & 9 & 10 & 9 \\
\hline \multirow{5}{*}{$\begin{array}{c}\text { C.2. } \\
\text { Expansion joints }\end{array}$} & Standard rating & 2,9 & 2,9 & 4,7 & 4,4 & 3,1 \\
\hline & Standard deviation & 0,8 & 1,0 & 0,5 & 0,5 & 0,7 \\
\hline & Median & 3 & 3 & 5 & 4 & 3 \\
\hline & Mode & 2 & 4 & 5 & 4 & 3 \\
\hline & Frequency & 6 & 5 & 11 & 9 & 11 \\
\hline \multirow{5}{*}{$\begin{array}{l}\text { C.3. } \\
\text { Bearings }\end{array}$} & Standard rating & 2,1 & 2,3 & 2,5 & 2,5 & 2,2 \\
\hline & Standard deviation & 1,3 & 0,6 & 0,8 & 0,8 & 0,4 \\
\hline & Median & 2 & 2 & 2 & 2 & 2 \\
\hline & Mode & 1 & 2 & 2 & 2 & 2 \\
\hline & Frequency & 6 & 12 & 9 & 10 & 12 \\
\hline \multirow{5}{*}{$\begin{array}{c}\text { D.1. } \\
\text { pavement/ } \\
\text { footways }\end{array}$} & Standard rating & 4,0 & 2,3 & 2,8 & 3,7 & 2,1 \\
\hline & Standard deviation & 0,8 & 0,9 & 1,0 & 0,6 & 0,5 \\
\hline & Median & 4 & 2 & 2 & 4 & 2 \\
\hline & Mode & 4 & 2 & 2 & 4 & 2 \\
\hline & Frequency & 5 & 11 & 8 & 8 & 14 \\
\hline \multirow{5}{*}{$\begin{array}{c}\text { D.2.1. } \\
\text { Traffic barriers }\end{array}$} & Standard rating & - & 2,5 & 3,1 & - & - \\
\hline & Standard deviation & - & 0,7 & 1,1 & - & - \\
\hline & Median & - & 3 & 3 & - & - \\
\hline & Mode & - & 3 & 2 & - & - \\
\hline & Frequency & - & 7 & 6 & - & - \\
\hline \multirow{5}{*}{$\begin{array}{l}\text { D.2.2. } \\
\text { Railing }\end{array}$} & Standard rating & 4,0 & 2,5 & 3,2 & 3,0 & 3,5 \\
\hline & Standard deviation & 0,9 & 0,7 & 1,1 & 0,9 & 1,0 \\
\hline & Median & 4 & 3 & 3 & 3 & 3 \\
\hline & Mode & 5 & 3 & 3 & 3 & 3 \\
\hline & Frequency & 6 & 7 & 7 & 6 & 6 \\
\hline \multirow{5}{*}{$\begin{array}{l}\text { D.3. } \\
\text { Other }\end{array}$} & Standard rating & 2,7 & 2,0 & 2,6 & 2,2 & 2,4 \\
\hline & Standard deviation & 0,5 & 0,0 & 0,5 & 0,4 & 0,5 \\
\hline & Median & 3 & 2 & 3 & 2 & 2 \\
\hline & Mode & 3 & 2 & 3 & 2 & 2 \\
\hline & Frequency & 11 & 15 & 9 & 12 & 9 \\
\hline
\end{tabular}

It can be concluded that the engineers who opted for ratings 1 and 2 (four of them) limited their inspection to the immediate condition of the element, while those who rated the element with 4 and 5 (seven engineers) adopted a wider perspective standpoint and noted that the element is directly endangered and that it is a menace to safe operation of traffic. Four engineers who decided to give a medium ranking (3) probably did recognize the damage but did not consider it to be a menace to safety.

Median measures a mean value, i.e. a place in the centre of the group of ratings in the statistical distribution, and this in such 
a way that one half or ratings in the group has a value greater than the median, while the other half of ratings in the group has a value smaller than the median. According to the data, it is clear that the distribution of results according to standard deviation meets the condition of $\sigma<1.0$ for the group of damage ratings according to median 4 and 5 which represent considerable damage to the elements, i.e. their full uselessness. This means that one half of the damage presenting considerable threat to the structure was assessed within limits of the level of damage for one higher/lower rating. This data shows a satisfactory accuracy for visual observation which has been divided in this study into five levels.

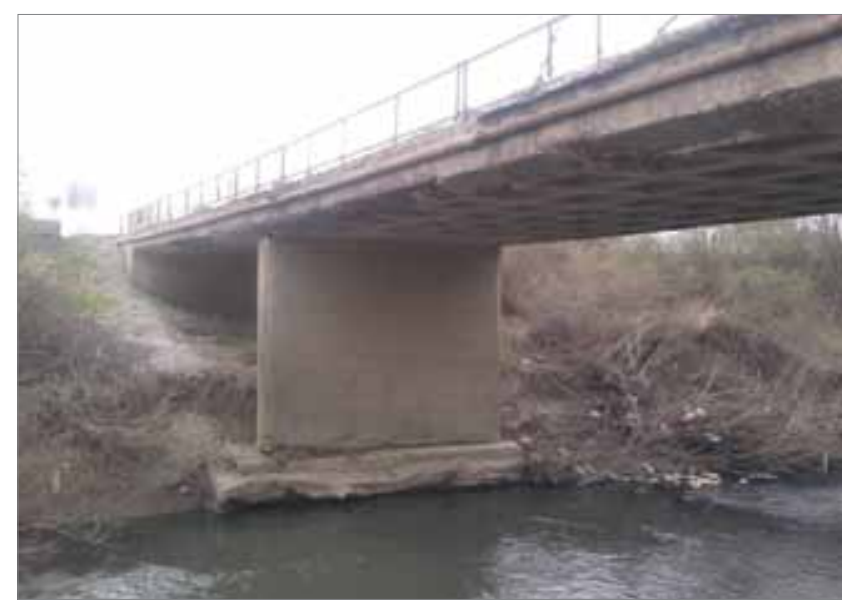

Figure 4. Bridge 1 abutments and piers at the time of inspection, with visible signs of scouring

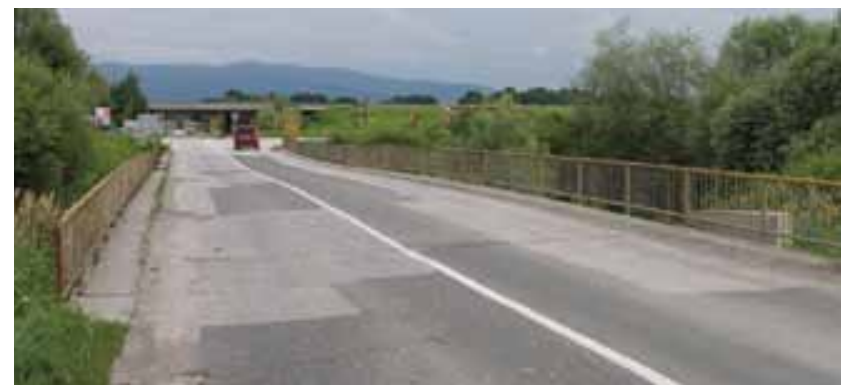

Figure 5. Pavement and railing, Bridge 1

Mode is a form of qualitative or quantitative property that occurs most frequently, i.e. a form of property with highest number of reiterations or with highest frequency. In case of nominal properties, the mode is defined by counting. For damage ratings with the reiteration frequency mode for more than one half of 15 respondents ( $f \geq 8$ ), the correspondence was registered in $62 \%$ of the total number of elements under study. Considering the odd sample of respondents, if the limit of the reiteration frequency mode is reduced to ( $f \geq 7$ ), the correspondence amounts to satisfactory $75 \%$ for the total number of elements under study. Inspectors mostly agree with one another with regard to visible manifestations of greater defects.
The relationship between the modal value and an average rating points to the diversity of variations within a group of damage ratings. If the decimal measure of an average value is excluded, and if the mathematical principle of rounding to the higher full rating is adopted, the diversity of ratings within a group can be derived by comparison with the mode for the same group of damage ratings. Greater diversity in individual ratings occurs in groups where the modal value and an average rating do not belong to the same damage rating level. This is the case in $17 \%$ of the total number of elements under study. This means that there is a significant dispersion of remaining results in the relationship of results belonging to the mode (rating with the greatest frequency of reiteration). As in this study there is no precise value that would be associated with individual elements of the bridge, the level of success of individual inspectors can be measured by deviation of their ratings for individual elements from the mean value: the lowest deviation points to the best inspector, and the highest to the least successful inspector. This principle is shown in Table 4: deviation from the mean value is calculated for each rating, and this deviation is a measure of success of inspectors.

Table 4. Deviation of ratings given by some inspectors from the mean value, example of ratings for the superstructure of the bridge 1

\begin{tabular}{|c|c|c|c|c|c|c|c|c|}
\hline \multirow{3}{*}{ Inspectors } & \multicolumn{8}{|c|}{ Superstructure - BRIDGE 1} \\
\hline & \multicolumn{2}{|c|}{ C.1.1. } & \multicolumn{2}{|c|}{ C.1.2. } & \multicolumn{2}{|c|}{ C.2. } & \multicolumn{2}{|c|}{ C.3. } \\
\hline & rating & dev. & rating & dev. & rating & dev. & rating & dev. \\
\hline 1 & 4 & 0,20 & 4 & 0,27 & 4 & 1,13 & 4 & 1,87 \\
\hline 2 & 4 & 0,20 & 4 & 0,27 & 2 & 0,87 & 4 & 1,87 \\
\hline 3 & 4 & 0,20 & 4 & 0,27 & 2 & 0,87 & 1 & 1,13 \\
\hline 4 & 4 & 0,20 & 4 & 0,27 & 3 & 0,13 & 2 & 0,13 \\
\hline 5 & 4 & 0,20 & 4 & 0,27 & 2 & 0,87 & 1 & 1,13 \\
\hline 6 & 4 & 0,20 & 2 & 1,73 & 2 & 0,87 & 2 & 0,13 \\
\hline 7 & 4 & 0,20 & 4 & 0,27 & 2 & 0,87 & 2 & 0,13 \\
\hline 8 & 3 & 0,80 & 3 & 0,73 & 3 & 0,13 & 1 & 1,13 \\
\hline 9 & 3 & 0,80 & 3 & 0,73 & 3 & 0,13 & 1 & 1,13 \\
\hline 10 & 4 & 0,20 & 5 & 1,27 & 4 & 1,13 & 5 & 2,87 \\
\hline 11 & 4 & 0,20 & 4 & 0,27 & 3 & 0,13 & 3 & 0,87 \\
\hline 12 & 4 & 0,20 & 4 & 0,27 & 4 & 1,13 & 2 & 0,13 \\
\hline 13 & 3 & 0,80 & 3 & 0,73 & 3 & 0,13 & 1 & 1,13 \\
\hline 14 & 4 & 0,20 & 4 & 0,27 & 2 & 0,87 & 1 & 1,13 \\
\hline 15 & 4 & 0,20 & 4 & 0,27 & 4 & 1,13 & 2 & 0,13 \\
\hline Average & 3,8 & & 3,73 & & 2,87 & & 2,13 & \\
\hline $\begin{array}{l}\text { Standard } \\
\text { deviation }\end{array}$ & 0,41 & & 0,7 & & 0,83 & & 1,3 & \\
\hline
\end{tabular}


Table 5. The number of the lowest and highest deviations of ratings from the mean value, as related to inspectors and bridges

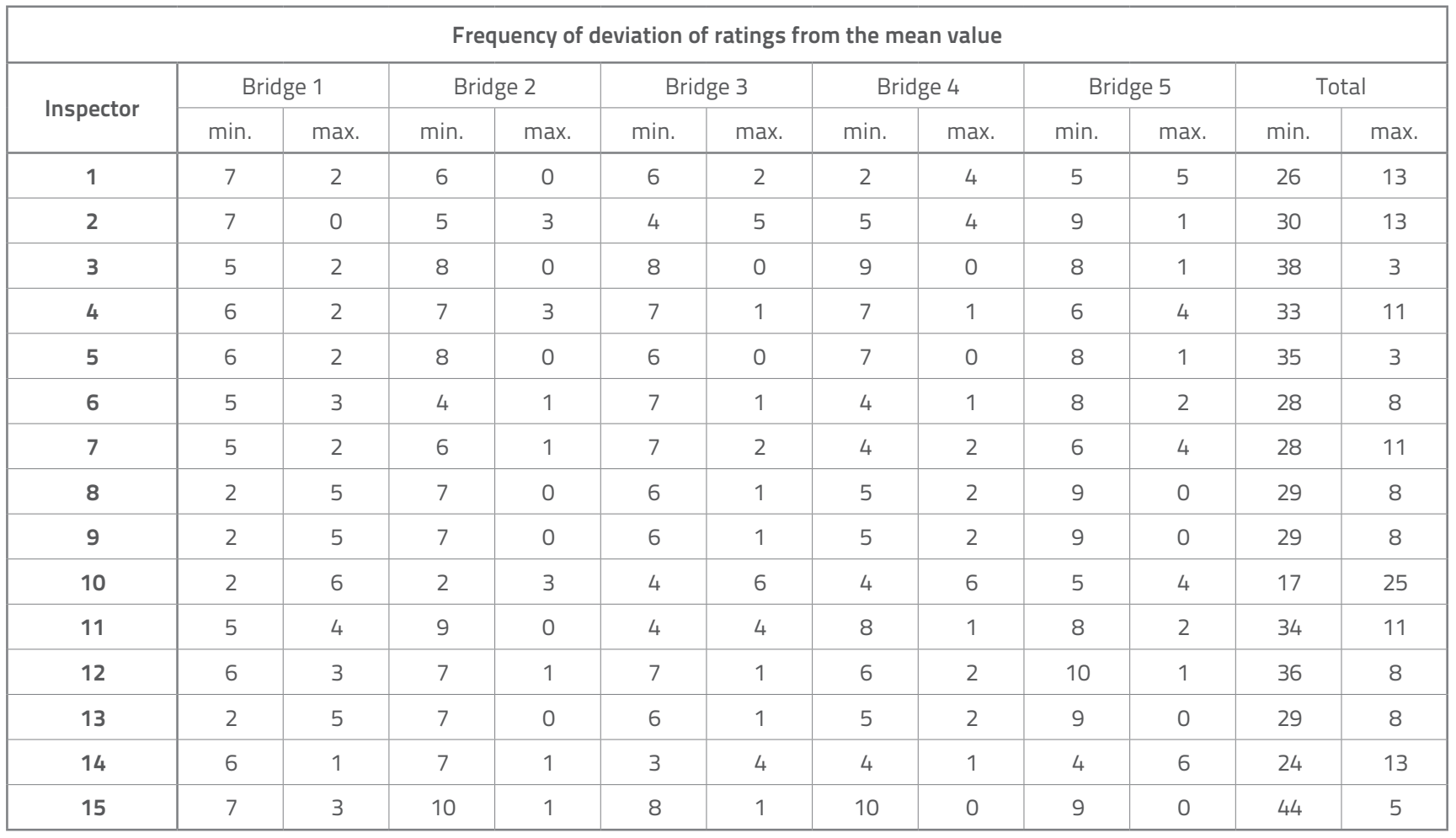

By counting frequencies of ratings that deviate the most/ least from an average value for each inspector and for each bridge, we can make conclusions about similarity of criteria used by inspectors to assess bridge damage. The number of ratings by which each inspector is the closest to and farthest from the average value is given in Table 5.

The frequency of occurrence of absolutely worst results of the same inspector in 4 out of 5 examples was registered by considering absolute deviations from mean values. Such a great deviation of one inspector's results from usual results of other inspectors shows that the said inspector used criteria that differ greatly from those used by other inspectors.

The title of an absolutely best inspector according to five examples was obtained two times by the same person, while in the remaining three examples this title was obtained by other inspectors. It can be concluded that ratings given by inspector 10 can be considered disputable, while inspector 3 is, on an average, closest to the mean value. It should be noted that this assessment of inspectors can not be interpreted as absolute, as comparison with mean value is not an exact indication. It is however a good indication for the harmonization of different criteria.

\section{Proposals for improving the bridge condition assessment system}

The basic objective of this study was to check uniformity of bridge inspections that are carried out in the scope of preparation of periodic maintenance plans. It can generally be seen that in some types of damage there are great deviations in the ratings. Thus, different inspectors have given the entire range of ratings for some types of damage, from totally undamaged to unusable. This result suggests that continuous efforts should be made to improve the system which, although relatively well conceived, obviously has some deficiencies, especially in the way engineers perceive damage. It would be reasonable to propose organization of workshops for engineers performing visual inspection of bridges, but with a thorough preparatory work including production of good quality aids - inspection manuals. The existing manual is too general, and is characterized by a formalized approach to rating. The training of bridge engineers should be oriented toward deeper understanding of the deterioration process, including its consequences for the safety of traffic on national roads. Such workshops should be organized as a form of professional advancement. The training of engineers should focus on gaining a more extensive knowledge about bridge damage, so that they can recognize indications pointing to harmful influence of some deterioration mechanisms even before signs of damage appear on the surface.

\section{Conclusion}

Regardless of current technological advances, visual inspection is expected to remain the main aid for collecting data about condition of bridges. This study, and the corresponding 
analysis of results, point to the possibility of assessing quality of work of bridge engineers, and to types of damage that are difficult to identify and evaluate.

In general terms, the results gained in the course of this study point to a relatively good uniformity, especially if we take into account known problems associated with subjective and qualitative method of visual inspection of bridges. Sporadic cases of significant deviation of ratings are an indication for typical situations in practice. Such cases should be given a special attention through workshops and preparation of a bridge inspection manual.

According to the current methodology, the assessment of general condition of bridges is made by summing up damage identified at individual elements. In reality, bridge condition can generally be considered satisfactory despite a number of smaller defects. On the other hand, the condition of the bridge can be quite alarming even when local damage is scarce. In this respect, it is necessary to define solid criteria for the assessment of a general bridge condition based on visual inspection. General rating instructions should provide clear guidelines for the registration of visible manifestations of global condition (deformations, vibrations), and for heavy damage indicators (traffic, surrounding environment, regular maintenance). Local damage of elements should be given a minor role in the determination of general condition of bridges. In Croatia, some inspections backed by testing are conducted by specialists engaged as contractors for a specific work, while most routine inspections are made by employees of the road network operator and, at that, at least two systems are applied. It is highly significant to establish good communication between experts performing similar tasks, so that practical management of this significant and expensive national resource can be improved and harmonized through exchange of practical experience. It is also significant to make continuous efforts to motivate bridge inspectors for their work. An important step forward would be the implementation of existing regulations, and further elaboration of subordinate acts, in order to give to tasks related to structure management the same level of responsibility that already exists in activities related to construction work. More specifically, higher-level inspection findings/results should be attested with a certified engineer's seal.

\section{Acknowledgements}

This study has been realized with the support of the company Hrvatske ceste, and the data contained in the Road Database (BCP) were used. The authors extend their thanks to all competent authorities that have authorized this work and the use of relevant data, for their assistance and understanding. Special thanks are also extended to bridge inspection engineers for having agreed to participate in this study.

\section{REFERENCES}

[1] Kršinić, N.: Sustav za upravljanje i gospodarenje mostovima u Republici Hrvatskoj, Zbornik radova IV. kongresa DHGK, Hrvatsko društvo građevinskih konstruktora, J. Radić (ur.) Cavtat 1996., str. 87-93.

[2] Žugelj, V.: Hrvatski sustav za upravljanje i gospodarenje mostovima (HRMOS), Zbornik radova Četvrtog općeg sabora HDGK, Hrvatsko društvo građevinskih konstruktora, J. Radić (ur.), Brijuni, 1998., str. 231 - 236.

[3] Radić, J.: Prosudba utjecaja na trajnost mostova u Hrvatskoj, Zbornik radova prvog znanstvenog kolokvija "Mostovi", Društvo hrvatskih građevinskih konstruktora, Brijuni 1991., 219-232.

[4] Coren, S., Ward, L.M., \& Enns. J.T.: Sensation and Perception (5th edition). New York: JohnWiley \& Sons, Inc., 2003.

[5] Goldstein, E.B.: Osjeti i percepcija. Jastrebarsko: Naklada Slap., 2011.

[6] Radić, J. i dr.: BETONSKE KONSTRUKCIJE 4 - SANACIJE; poglavlje: Gospodarenje građevinama (Radić, J.; Bleiziffer, J.; Tkalčić, D.), Hrvatska sveučilišna naklada, Zagreb 2008., str.227-324.

[7] Guidelines for bridge management systems, American Association of State Highway and Transportation Officials AASHTO, Washington, 1993.

[8] Reliability of visual inspection for highway bridges, Volume I: Final Report, FHWA-RD-01-020 JUNE 2001, Research, Development, and Technology Turner-Fairbank Highway Research Center, US Department of Transportation, Federal Highway Administration

[9] Radić, J.; Velan, D.; Zekušić, L.: Osvrt na stanje cestovnih mostova u SR Hrvatskoj, Zbornik radova s XII. kongresa Saveza društava za puteve "Via Vita", Budva 1986., 259-262.

[10] Radić, J.; Šavor, Z.; Puž, G.; Bleiziffer, J.; Balažić, A.: Asset management system for croatian motorways, Proceedings of Fib symposium Concrete structures - Stimulators of development, SECON, Dubrovnik 2007, pg. 881.-888.

[11] Thompson, P.D.; Shepard, R.W.: AASHTO - Commonly recognized bridge elements, Materials for National Workshop on Commonly Recognized Measures for Maintenance, Scottsdale, Arizona, June, 2000.

[12] Pauše, Ž.: Uvod u matematičku statistiku, Školska knjiga, Zagreb, 1993. 